\title{
FEASIBILITY STUDY OF BUSINESS IN AGARWOOD INOCULATION AT DIFFERENT STEM DIAMETERS AND INOCULATION PERIODS
}

\author{
Sri Suharti ${ }^{1,2}$, Pratiwi ${ }^{1}$, Erdy Santosa ${ }^{1}$ and Maman Turjaman ${ }^{1}$
}

\begin{abstract}
Indonesia signifies as the biggest agarwood producer country in the world. Its demand and price tend to increase and have brought about over exploitation of agarwood. Consequently, its population in nature has decreased significantly. To overcome the situation, since 1995, agarwood has been included in the CITES Appendix II. However, illegal exploitation remains persistent and reaches an excessive level. In order to deal with it, agarwood cultivation and its artificial production have been undertaken at several provinces in Indonesia. Some supporting factors for agarwood cultivation and artificial production are the availability of potential land for extensive cultivation, appropriate agro climate condition, simple cultivation technique and already being well adopted by farmers, the availability of necessary pathogen for agarwood inoculation, and the increasing demand with relatively high price. The research aims to analyze the feasibility study of agarwood inoculation business at several stem diameters $(15-25 \mathrm{~cm}$; 26 $35 \mathrm{~cm}$ and $36-40 \mathrm{~cm}$ ) and periods of inoculation (1 - 5 years). Data were collected through field observation and literature study. The results showed that inoculation on agarwood producer tree stands at $12.5 \%$ interest rate afforded positive net present value (NPV), internal rate of return (IRR) is much higher than market interest and benefit cost $(B / C)$ ratio $>2$ for those three diameter classes. Furthermore, if agarwood harvesting is delayed until five years after inoculation, NPV, IRR and B/C ratio would be much higher. It can be concluded that inoculation on agarwood producer tree stands (at appropriate age for inoculation) is feasible to be developed.
\end{abstract}

Keywords: Feasibility, inoculation, production, price, diameter, agarwood

\section{INTRODUCTION}

Agarwood is produced from certain infected tree species that grow prevalently in tropical area and generally originated from genus Aquilaria, Gyrinops and Gonystylus which are classified in Thymeleaceae family. Genus of Aquilaria consists of 15 species, growing on particular sites of tropical Asia such as India, Pakistan, Myanmar, Lao PDR, Thailand, Cambodia, South China, Malaysia, Philippine and Indonesia. Among those species, six are found in Indonesia, i.e. A. malaccensis, $A$. microcarpa, $A$. hirta, $A$.

\footnotetext{
${ }^{1}$ Forest Conservation and Rehabilitation Research and Development Center,

Jl. Gunung Batu No. 5, Bogor, 16610.

${ }_{2}^{2}$ Corresponding Author: E-mail: suharti23@yahoo.co.id
} 
beccariana, A. cumingiana and A. filaria. Their growth disperses in almost all of Indonesian islands. Gonystylus genus has 20 species, scattering in Southeast Asia regions until Solomon and Nicobar archipelago. Gyrinops genus has seven species. Six out of seven are found in East part of Indonesia and one species encountered in Srilanka (Anonymous, 2002; Aswandi, 2009).

Many people fail to notice the clear distinction between agarwood and the host tree stands that produce agarwood. SNI 01-5009.1-1999 defines agarwood as a kind of wood with different forms and distinctive colors which contains aromatic resin originated from trees or part of trees that naturally grow or becomes dead as a result of infection process either through natural or artificial process. Among the chemical composition in all agarwood, its aromatic resin is mostly found on Aquilaria sp. Agarwood with high economic value is the stuff located in the sapwood portion (called 'gubal') of the host tree stands, which emerge after that portion has been infected or died (Persoon, 2007). Meanwhile, the corresponding host tree stands refer to those whose particular portions (particularly sapwood) is able to develop the so-called agarwood either naturally or artificially.

Indonesia signifies as the biggest agarwood producer in the world and the host trees that produce such agarwood consisting of 16 species. In 1985, the export of agarwood from Indonesia reached 1,487 tons. The high agarwood price has induced its excessive exploitation, not only from died agarwood tree but also by cutting down the living agarwood tree. As a result, agarwood species became depleted, scarce or even vanished. Therefore in 1995, CITES included A. malaccensis, as one of the best agarwood producer tree species, into Appendix II. Since then, agarwood export has been limited with a quota of only 250 ton/year (Blanchette, 2006).

In 2000, Indonesia's Agarwood Exporter Association (Asgarin) conducted a survey to identify the population of natural agarwood tree stands at several forest areas. The result showed that their relative population in Sumatera, Kalimantan, Nusa Tenggara, Sulawesi, Maluku and Papua was 26, 27, 5, 4, 6 and 37\% respectively (Adijaya, 2009). Subsequently, another study on agarwood population revealed that in Sumatera, Kalimatan and Papua, average agarwood population reached only 1.87, 3.37 and 4.33 trees/ha respectively (Anonymous, 2008).

In order to anticipate the increasing demand and to evade agarwood in nature to become extinct, several efforts to cultivate trees producing agarwood have started to develop in many areas of Indonesia such as North Sumatera, Riau, Jambi, West Java, West Nusa Tenggara, South Kalimantan and West Kalimantan. Agarwood cultivation that is increasing especially after conducting several researches show that cultivated agarwood could provide feasible benefit (Marliani, 2008; Suharti, 2009; Tarmiji, 2009; The Angel, 2009).

Some supporting factors for agarwood cultivation consist of the availability of potential land for extensive agarwood cultivation, appropriate agro climate condition, simple cultivation technique and being already well adopted by farmers, availability of 
necessary pathogen of agarwood inoculation and the increasing demand with relatively high price. The key of agarwood agribusiness mainly lies on the success of pathogen inoculation technique, pathogen suitability for the inoculation with inoculated trees and resistance level of such trees. If those three requirements could be met, agarwood could be initially harvested one year after inoculation. This paper describes feasibility study of agarwood inoculation at several stem diameters and harvesting periods after the corresponding host trees that have been inoculated.

\section{MATERIALS AND METHODS}

\section{A. Type and Source of Data}

The pertinent data were collected from three field survey areas: Carita-Banten, West Kalimantan and Kandangan-South Kalimantan (primary data) and literature study (secondary data). Data collection was conducted from 2008 - 2010. Those data included ecological aspect and agarwood distribution, age, diameter, price of trees prepared for inoculation, cost of labor, price of inoculation material and chemical compound, price and depreciation value for tools and equipment used for the inoculation process as well as price of agarwood at different qualities. Meanwhile, source of secondary data and information was coming from Ministry of Forestry, CITES, Statistical Centre Bureau (BPS) and Indonesia's Agarwood Exporter Association (Asgarin).

\section{B. Data Analysis}

The collected data were scrutinized in depth using financial analysis, like Net Present Value (NPV), Internal Rate Of Return (IRR) and Benefit Cost Ratio (B/C ratio). The formulas are as follows (Grey et al., 1987):

a. $\mathrm{NPV}=\sum_{t=0}^{n} \frac{\mathrm{Bt}-\mathrm{Ct}}{(1+\mathrm{i})^{\mathrm{t}}}$

where:

$\mathrm{NPV}=$ net present value,

$\mathrm{Bt}=$ benefit or revenue at year $\mathrm{t}$,

$\mathrm{Ct}=$ cost at year $\mathrm{t}$,

$\mathrm{i}=$ interest rate of the bank,

$\mathrm{n} \quad=$ period of project. 
A project is considered as financially feasible if the NPV is $>0$.

b. $I R R=i 1+\frac{N P V 1}{N P V 1-N P V 2}(i 2-i 1)$

Where:

IRR = internal rate of return,

i1 = interest rate to produce NPV1 positive close to zero,

NPV1 = value of NPV close to zero positive,

i2 = interest rate to produce NPV2 negative close to zero,

NPV2 = value of NPV close to zero positive.

A project is considered as financially feasible if the IRR value is higher than the interest rate from bank.

c. $B / C=\frac{\sum_{T=0}^{n} \frac{B t}{(1+i)^{t}}}{\sum_{t}^{n} \frac{C t}{(1+i))^{t}}}$

Where:
$\mathrm{B} / \mathrm{C}=$ benefit cost ratio,
$\mathrm{Bt}=$ benefit or revenue at year $\mathrm{t}$,
$\mathrm{Ct}=$ cost at year $\mathrm{t}$,
$\mathrm{i}=$ interest rate,
$\mathrm{n} \quad=$ period of project.

A Project is considered as financially feasible if the $\mathrm{B} / \mathrm{C}$ ratio $>1$.

\section{Assumptions and Restrictions}

Several assumptions and restrictions in this research are:

a. Trees producing agarwood used in this research are bought from farmers. They consist of three different stem diameters $(15-25 \mathrm{~cm}, 26-35 \mathrm{~cm}$ dan $36-40 \mathrm{~cm})$ with the total of 300 stems ( 100 trees for each diameter).

b. The price of each tree is $R p 100,000 ; R p 125,000$ and $R p 150,000$ for diameter 15 - 25 $\mathrm{cm} ; 26-35 \mathrm{~cm}$ and $36 \mathrm{~cm}-40 \mathrm{~cm}$, respectively.

c. Number of trees alive and successfully inoculated reachs $90 \%$ from the total initial population (90 trees). Agarwood harvesting is done periodically (once a year), starting from one year until five year after inoculation (20\% per year). Hence every year there are 18 trees $(20 \%)$ harvested.

d. Productivity of agarwood is assumed as follows (Table 1):

- For stem diameter of $15-25 \mathrm{~cm}$, agarwood production with high quality varies from 0.4 to $1 \mathrm{~kg} /$ tree whereas low quality production varies from 3 to $7 \mathrm{~kg} /$ tree. 
- For stem diamater of $26-35 \mathrm{~cm}$ agarwood production with high quality varies from 0.5 to $1.1 \mathrm{~kg} /$ tree while low quality production varies from 4 to $8 \mathrm{~kg} /$ tree.

- For stem diameter of $36-40 \mathrm{~cm}$ agarwood production with high quality varies from 0.6 to $1.2 \mathrm{~kg} /$ tree and low quality production varies from 5 to $9 \mathrm{~kg} /$ tree.

Table 1. Productivity of agarwood at different stem diameters and ages of tree host

\begin{tabular}{|c|c|c|c|c|c|c|}
\hline \multirow{3}{*}{$\begin{array}{l}\text { Period of harvesting } \\
\text { agarwood after } \\
\text { inoculation } \\
\left.\text { (years) }^{*}\right)\end{array}$} & \multicolumn{2}{|c|}{ Diameter $15-25 \mathrm{~cm}$} & \multirow{2}{*}{\multicolumn{2}{|c|}{$\begin{array}{c}\text { Diameter } 26-35 \mathrm{~cm} \\
\text { Production } \\
(\mathrm{kg} / \text { tree })\end{array}$}} & \multirow{2}{*}{\multicolumn{2}{|c|}{$\frac{\text { Diameter } 36-40 \mathrm{~cm}}{\text { Production }(\mathrm{kg} / \mathrm{tree})}$}} \\
\hline & \multicolumn{2}{|c|}{ Production (kg/tree) } & & & & \\
\hline & $\begin{array}{l}\text { High } \\
\text { quality }\end{array}$ & $\begin{array}{l}\text { Low } \\
\text { quality }\end{array}$ & $\begin{array}{l}\text { High } \\
\text { quality }\end{array}$ & $\begin{array}{c}\text { Low } \\
\text { quality }\end{array}$ & $\begin{array}{c}\text { High } \\
\text { quality }\end{array}$ & $\begin{array}{c}\text { Low } \\
\text { quality }\end{array}$ \\
\hline 1 & 0.40 & 3 & 0.50 & 4 & 0.60 & 5 \\
\hline 2 & 0.55 & 4 & 0.65 & 5 & 0.75 & 6 \\
\hline 3 & 0.70 & 5 & 0.80 & 6 & 0.90 & 7 \\
\hline 4 & 0.85 & 6 & 0.95 & 7 & 1.05 & 8 \\
\hline 5 & 1.00 & 7 & 1.10 & 8 & 1.20 & 9 \\
\hline
\end{tabular}

") Age of agarwood trees after inoculation (years)

e. Cost for agarwood harvesting is $\mathrm{Rp} 100,000 / \mathrm{kg}$ (similar for the production of both high and low quality).

f. For the inoculation of as many as 100 agarwood trees, the work will take about 10 days if implemented by labor with the following skills:

- technical specialist performing the inoculation with the salary $R p$ 150,000/ man day

- technical assistant for inoculation with the salary Rp 100,000/man day, and

- labour carrying equipment and inoculation material with the salary Rp 150,000/man day

g. Price of agarwood at different harvesting periods for high and low quality product (Table 2$)$.

Table 2. Price of agarwood at different harvesting period

\begin{tabular}{|c|c|c|c|c|c|}
\hline \multirow{3}{*}{$\begin{array}{l}\text { Period of agarwood } \\
\text { harvesting after } \\
\text { inoculation (years) }\end{array}$} & \multicolumn{4}{|c|}{ Price of agarwood } & \multirow{3}{*}{ Note } \\
\hline & \multicolumn{2}{|c|}{ High/Super quality } & \multicolumn{2}{|c|}{ Low quality } & \\
\hline & US \$ & $\left.\mathrm{Rp}^{*}\right)$ & US \$ & $\mathrm{Rp}^{* *}$ & \\
\hline 1 & 100 & 900,000 & 25 & 225,000 & $1 \mathrm{US} \$=\operatorname{Rp} 9,000$ \\
\hline 2 & 200 & $1,800,000$ & 25 & 225,000 & \\
\hline 3 & 500 & $4,500,000$ & 25 & 225,000 & \\
\hline 4 & 750 & $6,750,000$ & 25 & 225,000 & \\
\hline 5 & 1000 & $9,000,000$ & 25 & 225,000 & \\
\hline
\end{tabular}

h. Interest rate used in this financial analysis is $12.5 \%$ per year 


\section{RESULTS AND DISCUSSION}

\section{A. Ecological Aspect and Agarwood Distribution in Indonesia}

Agarwood exerts an important role in Indonesia as it contributes to country's foreign exchange. High economic value of agarwood has induced agarwood to become one of the prominent commodities in Indonesia (Pratiwi et al., 2010). According to its natural habitat, agarwood grows well at low to hilly land ( $<750$ meter above sea level). Aquilaria spp. grows optimally on yellow red podzolic soil, clay sandy soil with moderate to good drainage system, A - B climate, $80 \%$ humidity level, average temperature between 22 and $28{ }^{\circ} \mathrm{C}$ and average annual rainfall in the range between 2,000 and 4,000 mm. Agarwood trees will not grow well on inundated soil, swamp area, soil solum thickness less than $50 \mathrm{~cm}$, and quartz sand as well as soil with the acidity level less than 4 (Rizlani and Aswandi, 2009).

Until this occasion, agarwood is produced by tropical tree species after being infected by fungi, such as Aquilaria spp., Gonystylus spp., Wikstroemeae spp., Enkleia spp., Aetoxylon spp., Gyrinops spp. (Sidiyasa et al., 1986; Chakrabarty et al., 1994) and Excocaria agaloccha (Sidiyasa et al., 1986; Chakrabarty et al., 1994; Sudarmalik et al., 2006; Sumarna, 2008). Those tree species are spread out at several Indonesia islands and their more related description is presented in Table 3.

Agarwood producing trees could grow well at different ecosystems and forest types. Pratiwi et al. (2010) showed that the performance of agarwood producing trees, especially A. crassna and A. microcarpa in Dramaga and Kampung Tugu (Sukabumi) are better than those in Carita. The environmental condition of those three locations are almost similar, i.e. 'A' type of rainfall, temperature average about $20-30^{\circ} \mathrm{C}$, humidity level of 77 to $85 \%$, and topography varies from flat to undulating. It seems that the differences in performance among agarwood producing tree species in those three locations are influenced by the soil fertility characteristics. Soil in Carita might have been further decomposed compared to that in the other two locations (Dramaga and Kampung Tugu), hence the soil fertility is lower in Carita than Sukabumi locations. 
Table 3. Agarwood producing tree species in Indonesia

\begin{tabular}{clll}
\hline No. & \multicolumn{1}{c}{ Botanic name } & Family & \multicolumn{1}{c}{ Growth distribution } \\
\hline 1. & Aquilaria malaccensis & Thymeleaceae & Sumatera, Kalimantan \\
2. & A. hirta & Thymeleaceae & Sumatera, Kalimantan \\
3. & A. filaria & Thymeleaceae & Nusa Tenggara, Maluku, Irian \\
& & & Jaya \\
4. & A. microcarpa & Thymeleaceae & Sumatera, Kalimantan \\
5. & A. agalloccha & Thymeleaceae & Sumatera, Kalimantan, Java \\
6. & A. beccariana & Thymeleaceae & Sumatera, Kalimantan \\
7. & A. seccunda & Thymeleaceae & Maluku, Irian Jaya \\
8. & A. moszkoreskii & Thymeleaceae & Sumatera \\
9. & A. tomentosa & Thymeleaceae & Irian Jaya \\
10 & Aetoxylon sympethalum & Thymeleaceae & Kalimantan, Irian Jaya, Maluku \\
11. & Enkleia malaccensis & Thymeleaceae & Irian Jaya, Maluku \\
12. & Wikstroemia poliantha & Thymeleaceae & Nusa Tenggara, Irian Jaya \\
13. & W. tenuriamis & Thymeleaceae & Sumatera, Kalimantan, Bangka \\
14. & W. androsaemofilia & Thymeleaceae & Kalimantan, Nusa Tenggara \\
& & & Timur, Irian Jaya, Sulawesi \\
15. & Gonystylus bancanus & Thymeleaceae & Sumatera,Kalimantan,Bangka \\
16. & G. macrophyllus & Thymeleaceae & Kalimantan, Sumatera \\
17. & G. cumingiana & Thymeleaceae & Nusa Tenggara, Irian Ja ya \\
18. & Gyrinops rosbergii & Thymeleaceae & Nusa Tenggara \\
19. & G. versteegii & Thymeleaceae & Nusa Tenggara \\
20. & G. moluccana & Thymeleaceae & Maluku, Halmahera \\
21. & G. decipiens & Thymeleaceae & Sulawesi Tengah \\
22. & G. ledermanii & Thymeleaceae & Irian Jaya \\
23. & G. salicifolia & Thymeleaceae & Irian Jaya \\
24. & G. audate & Thymeleaceae & Irian Jaya \\
25. & G. podocarpus & Thymeleaceae & Irian Jaya \\
26. & Dalbergia farviflora & Leguminosae & Sumatera, Kalimantan \\
27. & Excocaria agaloccha & Euphorbiaceae & Java, Kalimantan, Sumatera \\
\hline & & &
\end{tabular}

Source: Sudarmalik et al. (2006)

Another study conducted by Sumarna (2008) in Jambi (Tabir Angin sub district, Merangin Regency) revealed that based on habitat ecology (shown by distribution of host trees of $A$. malaccensis and A.microcarpa) confirmed that tree species studied could grow well at $100 \mathrm{~m}$ above sea level, with average temperature of $27^{\circ} \mathrm{C}$, relative humidity $78 \%$ and light intensity $75 \%$. They could also grow well at $200 \mathrm{~m}$ above sea level with average temperature of $24^{\circ} \mathrm{C}$, relative humidity $85 \%$ and light intensity around $67 \%$. Meanwhile, at $200 \mathrm{~m}$ above sea level, they grow well with average temperature of $20^{\circ} \mathrm{C}$ relative humidity about $81 \%$ and light intensity around $56 \%$. 
Based on the two studies, it can be assumed that Aquilaria spp. could grow well on areas with average temperature of $20-33^{\circ} \mathrm{C}$, relative humidity varies from $77-85 \%$ and light intensity between 56-75\%. However, optimum environmental factors for agarwood production still need further studied.

\section{B. Artificial Agarwood Development through Inoculation Process}

Inoculation process typifies an important aspect in agarwood agribussiness. Since agarwood resin will not be easily formed naturally, human intervention is needed to render trees wounded and afterwards those trees are provided with the agarwood stimulating materials such as fungi and other substances to accelerate such agarwood formation (inoculation process).

After agarwood producing trees reach five years old and their stem diameter grows already at least $15 \mathrm{~cm}$, artificial process to induce agarwood formation could already be initiated. The process is done through the inoculation using particular fungi that render the inoculated trees prone to the disease, thereby inducing agarwood formation. The fungi should be compatible with the inoculated trees. Afterwards the artificially formed agarwood could be immediately harvested one or two years after inoculation. Harvesting could be done before the trees die, however, agarwood is best harvested on the dead trees because three types of agarwood products: gubal, kemedangan and ash/powder could be obtained all at once (Sumarna, 2007).

The fungi commonly used for inoculation process comprises of Fusarium sp., Phialopora parasitica, Torula sp., Aspergillus sp., Penicillium sp., Cladosporium sp., Epicoccum granulatum, Clymndrocladium sp., Sphaeropsis sp., Botryodiplodia theobromae, Trichoderma sp., Phomopsis sp., Chunninghamella echinulata (Anonymous, 2009). Basically, inoculated fungi would get the trees injured (wounded). This open wound will then stimulate trees to produce resin from woody tissue. Method of inoculation varies, depending on the size of the holes for inflicting wounds and how to prepare such holes. Holes with $5 \mathrm{~mm}$ diameter are usually prepared to make their distribution more dense (the distance between the holes is $5 \mathrm{~cm}$ ). Hence in a tree stem, thousands of holes could be prepared. If the size of holes is bigger, the distance between holes shoud be wider, therefore trees could still stand-firm against violent wind. Physiological process mechanism of agarwood production begins when the deseaseinducing microbes enters woody tissue. In order to survive, those microbes utilize liquid cell from woody tissue as source of energy and food. Gradually, the loss of such liquid cell would decrease the intensity of the metabolism process by tree woody tissues in transferring nutrients throughout the tree parts.

Tissue cells, that have been eaten up by microbes will develop collection of dead cell at artery tissues. As a result, the function of leaves in processing nutrient is inhibited and eventually terminates. The tree leaves will then turn yellowish and the trees subsequently die. Physically, tree branches and twigs are getting dry and stem skin (bark) is broken and therefore easy to remove (pull off). This phenomena could 
biologically describe how trees to respond in producing agarwood. In simple words, agarwood is developed as a result of tree response due to pathogen infection, injury or stress.

With the purpose of obtaining agarwood with gubal or kemedangan quality, five year old Aquilaria spp. tree was inoculated by using fusarium (fungi). Inoculation process was considered successful if brownish scratch appears followed by falling leaves before cut down. The level of success over the inoculation process varies. The least amount of artificial agarwood production at seven years old tree (two years after inoculation) reaches about $1 \mathrm{~kg}$ of gubal, $10 \mathrm{~kg}$ of kemedangan and $15 \mathrm{~kg}$ of ash/powder. Super quality of agarwood, comes from the felled down trees already dead for quite long, and becoming mixed up with the surrounding soil. Naturally, gubal, best quality agarwood is getting more difficult to acquire due to over exploitation of agarwood. It is estimated that best quality of agarwood could only be found on the trees which grow deep in the forest and taken about several weeks to get such agarwood.

Internationally, the price of gubal agarwood (super double) as indicated by blackish color could reach Rp 25 million $/ \mathrm{kg}$. In spite of its expensive price, the demand for gubal and kemedangan agarwood in international market keeps increasing. Several of the main agarwood-importer countries include Arab Saudi, Taiwan, Singapore, Korea, Hongkong and Japan (Anonymous, 2008).

Inoculation of fusarium is a crucial process to stimulate agarwood production and unless it is done carefully this could cause death of the inoculated tree and hence instigate lots of loss and failure. This situation might be caused by the use of fusarium for the inoculation that performs too savage to the trees. Violent fusarium may render the trees viciously attacked that further instigate their death. Another problem in the inoculation might also be attributed to the failure of the inoculating fungi to respond since each tree species exhibits different reaction. Such failure could be caused also by unsuitability of pathogen inoculated on the trees. Appropriateness of the inoculating microbes with trees holds a crucial factor that should be met. Therefore, one important factor that determines the success of inoculation process is to find out pathogen microbes to suit tree species as each tree species apparently fits with only certain pathogen microbe (Duryatmo, 2009).

\section{Market Prospect and Agarwood Business}

As mentioned before, demand on agarwood, tends to increase far beyond its supply capability. The rise of agarwood's demand is induced by the increase in utility variations as a result of progress in science and industrial technology. Agarwood is not only used as an aromatic material in perfume industry, but also employed for medicinal raw material, cosmetics, incense and preservative for accessories. Advancement in medical technology has proven that agarwood clinically could be efficacious as elixir for anti asthmatic, anti microbe, and as stimulant for neuron work and digestion. In ancient China, agarwood was used as therapeutic treatment for stomachache, pain killer, 
cancer, tumor, diarrhea, kidney problem and lungs problem. In Europe and India, agarwood is mainly employed for cancer medicinal treatment. Furthermore, in other countries like Singapore, China, Korea, Japan, and United States, agarwood is developed as anti depressant and also used as medical treatment for, stomachache, kidney problem, asthma, cirrosis of liver.

Besides, several particular communities require aromatic component as released from the burnt agarwood for religious ceremonial activities or rituals (Anonymous, 2010). Description of agarwood trade in Indonesia published by CITES in 2003 is presented at Table 4.

Table 4. Figures of agarwood (Aquilaria spp.) production and export in Indonesia during 1995-2003

\begin{tabular}{|c|c|c|c|c|c|}
\hline Year & $\begin{array}{l}\text { Quota of } \\
\text { production at } \\
\text { formal } \\
\text { harvesting *) }\end{array}$ & $\begin{array}{l}\text { Actual quota of } \\
\text { production *) }\end{array}$ & $\begin{array}{c}\text { Actual export } \\
\text { based on CITES } \\
\text { Indonesia *) }\end{array}$ & $\begin{array}{l}\text { Net export } \\
\text { report } \\
\text { CITES } * \text { ) }\end{array}$ & $\begin{array}{l}\text { Total export of } \\
\text { agarwood } \\
\text { (all species) } *)\end{array}$ \\
\hline 1995 & $\mathrm{n} / \mathrm{a}$ & $\mathrm{n} / \mathrm{a}$ & $\left.\mathrm{n} / \mathrm{a}^{* * * *}\right)$ & 323,577 & $\mathrm{n} / \mathrm{a}$ \\
\hline 1996 & 300,000 & 160,000 & $\begin{array}{l}299,523 \text { (including } \\
\text { A. filaria and } \\
\text { other species) }\end{array}$ & 293,593 & 299,593 \\
\hline 1997 & 300,000 & 120,000 & $\begin{array}{l}287,002 \text { (including } \\
\text { A. filarial } 180,000 \\
\mathrm{~kg} \text { ) }\end{array}$ & 305,483 & 287,002 \\
\hline 1998 & 150,000 & 150,000 & 148,238 & 147,212 & $\mathrm{n} / \mathrm{a}$ \\
\hline 1999 & 300,000 & 180,000 & 81,079 & 76,401 & 313,649 \\
\hline 2000 & 225,000 & 225,000 & 81,377 & 81,377 & 245,150 \\
\hline 2001 & 75,000 & 70,000 & 74,826 & 74,826 & 219,772 \\
\hline 2002 & 75,000 & 68,000 & 70,546 & $\mathrm{n} / \mathrm{a}$ & 175,245 \\
\hline 2003 & 50,000 & 50,000 & $\mathrm{n} / \mathrm{a}$ & $\mathrm{n} / \mathrm{a}$ & $\mathrm{n} / \mathrm{a}$ \\
\hline
\end{tabular}

*) CITES Management Authority of Indonesia

**) CITES Annual Report Data Compiled by UNEP-WCMC

$* * * \cdots) n /$ a: data not available

\#) the reason for the unavailability of data for 1995 and 1998 is not known

Table 4 shows that from 1995 to 2002, there was a significant decrease of agarwood export from Indonesia (nearly 40\%). The decrease in agarwood supply from Indonesia affected the agarwood price both at local (intermediate market) and in international market. In 1980, agarwood price at intermediate market was about $\mathrm{Rp} 30,000-$ $50,000 / \mathrm{kg}$ for low quality agarwood and $\mathrm{Rp} 80,000 / \mathrm{kg}$ for super quality agarwood. During that period, the agarwood price increased quite slowly and in 1993 its price was only Rp 100,000/kg. Extreme increase of agarwood price occurred in 1997 when there was an economic crisis in Indonesia. The price of agarwood increased tremendously and reached $\mathrm{Rp} 3-5$ million $/ \mathrm{kg}$. This price kept increasing and reached $\mathrm{Rp} 10$ million $/ \mathrm{kg}$ in 2000 and Rp 15 million/kg in 2009 (Wiguna, 2006; Adijaya, 2009). 
From the explanation above, it can be concluded that agarwood business is favorably potential and prospective to be developed especially in Indonesia that has biological potency such as availability of lots of agarwood producing tree species, plenty of potential forest area which is appropriate for agarwood cultivation and availability of supporting inoculation technique for agarwood cultivation.

Several attempts for agarwood cultivation has already been initiated since 1994/1995 by agarwood exporter company, i.e. PT. Budidaya Perkasa in Riau province. More than 10 ha of $A$. malaccensis tree stands were cultivated. Subsequently, Regional Forestry Service in Riau also developed agarwood cultivation at Syarif Hasim Grand Forest Park. In 2001 - 2002, some farmer groups were also interested to grow agarwood producing trees. As an example, farmer group in Pulau Aro Village, Tabir Ulu Sub District, Merangin Regency, Jambi, cultivated two agarwood species, i.e. $A$. malaccensis and A. microcarpa. Subsequently, in the village, at the end of 2002, there were 116 farmers under Penghijauan Indah Jaya farmer group (dealing with revegetation endeavor) developed 100 thousands of agarwood seedlings (Anonymous, 2008). In 2004/2005, Batanghari Watershed Management Institute (DAS BP Batanghari) in collaboration with Forestry Research and Development Agency (FORDA) established a demonstration plot of agarwood cultivation in private owned rubber cultivation (Sumarna, 2007).

\section{Investment Cost for Inoculation and Management}

To prepare a financial analysis about agarwood inoculation business, some investment and management costs are needed. Agarwood inoculation business typifies a capital intensive, hence the amount of currency needed to finance the activity is a lot. Detail costs for producing 100 agarwood tree species including investment, maintenance and harvesting are presented in Table. 5.

Investment cost consists of the cost for purchasing agarwood producing trees, inoculant materials, chemical substance, depreciation of the used equipment, fuel and the labor cost for inoculation process.

a. The cost for purchasing agarwood trees is $R p 100,000$; $R p 125,000$ and $R p 150,000$ with stem diameter of $15-25 \mathrm{~cm} ; 26-35 \mathrm{~cm}$ and $36-40 \mathrm{~cm}$ respectively.

b. The cost for purchasing inoculant material is $R p 100,000 ; R p 125,000$ and Rp 150,000 for stem diameter of $15-25 \mathrm{~cm} ; 26-35 \mathrm{~cm}$ and $36-40 \mathrm{~cm}$ respectively.

c. The cost for purchasing other chemical substance is $R p 60,000 ; R p 80,000$ and $\mathrm{Rp} 100,000$ for stem diameter $15-25 \mathrm{~cm} ; 26-35 \mathrm{~cm}$ and $36-40 \mathrm{~cm}$ respectively.

d. The cost of equipment and depreciation is $\mathrm{Rp} 1,010,000$ similar for all three stem diameter classes.

e. Fuel needed during inoculation process is $\mathrm{Rp} 450,000$ similar for all three stem diameter classes.

f. Cost of labor for performing inoculation process (specialist, assistant and unskilled labor) is Rp 4,000,000 similar for all three stem diameter classes. 
Maintenance cost after agarwood producing trees have been inoculated consists of cost for security and harvesting comprises:

a. Cost for security, calculated from the time when inoculation process was carried out until the end of harvesting period ( 1 - 5 years after inoculation), is Rp 12 million, similar for all three stem diameter classes.

b. Cost of harvesting is $R p 51.3$ million, $R p 61.2$ million and $R p 71.1$ million for each stem diameter $15-25 \mathrm{~cm} ; 26-35 \mathrm{~cm}$ and $36-40 \mathrm{~cm}$, respectively (Table 5).

Table. 5. Investment, management and harvesting cost of agarwood ( $\mathrm{Rp})$

\begin{tabular}{clrrr}
\hline No. & \multicolumn{1}{c}{ Type of Cost } & $\mathrm{D}=15-25$ & $\mathrm{D}=26-35$ & $\mathrm{D}=36-40$ \\
\hline 1. & Trees purchasing & $10,000,000$ & $12,500,000$ & $15,000,000$ \\
2. & Inoculant mater ial & $10,000,000$ & $12,500,000$ & $15,000,000$ \\
3. & Other chemical substance & $6,000,000$ & $8,000,000$ & $10,000,000$ \\
4. & Equipment & $1,010,000$ & $1,010,000$ & $1,010,000$ \\
5. & Fuel & 450,000 & 450,000 & 450,000 \\
& Specialist technical la bor & $1,500,000$ & $1,500,000$ & $1,500,000$ \\
6. & Technical assistant & $1,000,000$ & $1,000,000$ & $1,000,000$ \\
& Unskilled labor & $1,500,000$ & $1,500,000$ & $1,500,000$ \\
& Transfer of inoculant & $4,650,000$ & $9,300,000$ & $13,950,000$ \\
7. & Total cos t of inoculation & & & \\
& (2-7) & $26,110,000$ & $35,260,000$ & $44,410,000$ \\
8. & Cost for security & $12,000,000$ & $12,000,000$ & $12,000,000$ \\
9. & Harvesting cost & $51,300,000$ & $61,200,000$ & $71,100,000$ \\
\hline
\end{tabular}

\section{E. Feasibility of Agarwood Inoculation Business}

Based on assumption and restrictions mentioned above for the inoculation of 100 agarwood producing trees with average stem diameter of $15-25 \mathrm{~cm}$, total investment cost needed is $\mathrm{Rp} 36.11$ million consisting of cost for purchasing agarwood producing trees $\mathrm{Rp} 10$ million and cost for inoculation Rp 26.11 million. Besides, other cost for security of tree stands during 6 year period reaches $R p 12$ million and harvesting cost is Rp 51.3 million. Based on those investment, maintenance and harvesting costs, at 12.5 $\%$ interest rate, NPV obtained is $\mathrm{Rp} 180.198$ million, $\mathrm{IRR}=88.67$ and $\mathrm{B} / \mathrm{C}=3.53$ (Appendix 1).

Total investment cost for inoculation of agarwood producing trees with $25-35 \mathrm{~cm}$ stem diameter is $\mathrm{Rp} 47.76$ million. It covers the cost for purchasing agarwood producing trees ( $\mathrm{Rp} 12.5$ million) and the cost for inoculation process ( $\mathrm{Rp} 35.26$ million). Besides, the cost for securing tree stands during 6 years period reaches $\mathrm{Rp} 12$ million and harvesting cost is $\mathrm{Rp} 61.2$ million. Based on those investment, maintenance 
and harvesting cost, at $12.5 \%$ interest rate, the NPV obtained is Rp 199.74 million, $\mathrm{IRR}=82.58$ and $\mathrm{B} / \mathrm{C}=3.27$ (Appendix 2).

Total investment cost for inoculation of agarwood producing trees with $35-40 \mathrm{~cm}$ stem diameter is $\mathrm{Rp} 59.41$ million. It covers the cost for purchasing agarwood producing trees ( $\mathrm{Rp} 15$ million) and the cost for inoculation process ( $\mathrm{Rp} 44.41$ million). Besides, the cost for securing tree stands during 6 years period is $\mathrm{Rp} 12$ million and harvesting cost is $\mathrm{Rp} 71.10$ million. Based on those investment, maintenance and harvesting cost at $12.5 \%$ interest rate, the NPV obtained is $\mathrm{Rp} 219.28$ million, $\mathrm{IRR}=$ 78.45 and $\mathrm{B} / \mathrm{C}=3.1$ (Appendix 3).

The above financial analysis indicates that inoculation of agarwood producing trees needs an investment worth a big currency. However the potential benefit is also big and therefore it is very feasible to invest in agarwood inoculation and expectedly can pay off. The feasibility would be much higher if the harvesting period is postponed until five years after inoculation (when agarwood producing trees are 10 years old) (Table 6).

Table 6. Result of financial analysis of inoculation of 100 agarwood producing trees if harvested five years after inoculation

\begin{tabular}{clccc}
\hline No. & \multicolumn{1}{c}{ Criteria } & $\mathrm{D}=15-25 \mathrm{~cm}$ & $\mathrm{D}=26-<35 \mathrm{~cm}$ & $\mathrm{D}=36-40 \mathrm{~cm}$ \\
\hline 1. & NPV (DF 12.5\%) (Rp) & $403,959,683$ & $438,664,358$ & $473,369,034$ \\
2. & IRR (\%) & $86.11 \%$ & $80.25 \%$ & $76.14 \%$ \\
3. & B/C & 7.16 & 6.43 & 5.93 \\
\hline
\end{tabular}

Table 6 shows that postponing the harvest for five years after inoculation would afford NPV, IRR and B/C much higher than those of the earlier harvesting (Appendices 1, 2 and 3). Postponing for five years after inoculation would produce agarwood with better quality. However, many people who invest a lot of money in the business seem less preferred to postpone. They would rather gain quick benefit even with less amount of currency to obtain.

From the analysis above, it can be seen that agarwood agribusiness needs a big currency investment. Consequently only very limited people afford the capability to establish the business. For forest surrounding people who mostly have very limited access to the resources would not afford dealing with such big investment. Hence, in order to promote development of agarwood agribusiness wider, a partnership scheme should be initially introduced. Partnership model which is expected to be mutually advantages for both sides (investor and farmers or other parties) could endorse limited resources owner to develop agarwood agribusiness. Through partnership model, all risk, responsibilities and later benefit could be shared jointly among all the parties involved. 


\section{CONCLUSION}

Based on the calculation, analysis and the related scrutinize of this study, several remarks and recommendations can be drawn-up as follows:

1. Agarwood signifies one of the main non timber forest product commodities for export and other related business endeavors. Agarwood cultivation development and its artificial production are very prospective to be developed.

2. Several supporting factors favoring the success of agarwood cultivation development and its artificial production mainly lie on the availability of potential land for extensive agarwood cultivation, appropriate agro climate condition, cultivation technique which is relatively easy and has been well adopted by farmers, availability of necessary pathogen for agarwood inoculation and its demand that tends to increase with relatively high price.

3. Determining factors of the success of agarwood business comprise among others, inoculation technology, appropriateness/suitability between pathogen and tree species to be inoculated, and resistance of the inoculated tree species.

4. Development of agarwood agribusiness at different stem diameters, $(15-25 \mathrm{~cm}, 26$ $35 \mathrm{~cm}$ and $36-40 \mathrm{~cm}$ ) and periods of inoculation, would produce positive NPV, IRR much higher than the interest rate on national market and $\mathrm{B} / \mathrm{C}$ ratio $>1$, therefore it is very feasible to carry out the investment for such business.

5. In order to retain Indonesia as a prominent agarwood production country, to increase export of non timber forest product, and to improve income of forest surrounding people, several efforts to induce development of agarwood production tree species cultivation and agarwood production through artificial inoculation deserve extensive development.

6. As a capital intensive agribusiness, only few people afford the capability for such. In order to further develop agarwood agribusiness, a partnership scheme between big investors and other parties who own limited resources (farmers or other parties interested in agarwood development) should be initially introduced.

\section{ACKNOWLEDGEMENT}

The authors would like to highly appreciate the ITTO Project dealing with "Production and Utilization Technology for Sustainable Development of Agarwood (Gaharu) in Indonesia: PD 425/06 Rev.1 (I) which has greatly funded and provided the related facilities for this study. 


\section{REFERENCES}

Adijaya. 2009. Gaharu: Harta di kebun. Http://www.trubus-online.co.id/ mod.php? $\bmod =$ publisher\&p$=$ allmedia\&artid $=1625$. Accessed 13 February 2009.

Aswandi, 2009. Budidaya Gaharu: Alternatif pemberdayaan masyarakat desa hutan. Http://bpk-aeknauli.org/index.php?option $=$ com_content $\&$ task $=$ view\&id =74\&Itemid =1. Accessed, 12 February, 2009.

Blanchette, R.A. 2006. Sustainable agarwood production in Aquilaria trees. http:// forestpathology.cfans.umn.edu/agarwood.htm. Accessed 3 November 2008.

Chakrabarty, K., A. Kumar and V. Menon. 1994. Trade in Agarwood. WWF-Traffic India. 59 pp.

Duryatmo, S. 2009. Tersandung wangi gaharu. Trubus Online. http://www.trubusonline.co.id $/ \mathrm{members} / \mathrm{ma} / \mathrm{mod}$. php? $\mathrm{mod}=$ publisher\&op $=$ viewarticle\&cid $=1$ \&artid =1618. Accessed 16 February 2009.

Grey, C., P. Simanjuntak, L.K. Sabur and P.F.L. Maspaitella. 1987. Pengantar evaluasi proyek. Gramedia, Jakarta. 272p.

Marliani, L. 2008a. Suntikan inukolan - Sumber Majalah Trubus Indonesia http://gaharuman.blogspot.com/2008/09/suntikan-inokulan-sumber-majalahtrubus.html. Accessed 9 February 2009.

Marliani, L. 2008h. Wangian dari kebun. Http://gaharuman.blogspot.com/ 2008 09_01_archive.html. Accessed 5 November 2008.

Maximilian. 2008. Gaharu (Agarwood). Http://bisnisfarmasi.wordpress.com/ 2008/03/03/industri aromatic. Accessed 16 February 2009.

Persoon, G. 2007. Agarwood: The life of a wounded tree. IIAS Newsletter \# 45 Autumn 2007 pp24-25.

Pratiwi, E. Santoso and M. Turjaman. 2010. Karakteristik lahan habitat pohon penghasil gaharu di beberapa hutan tanaman di Jawa Barat. Info Hutan VII (2): 129-139.

Proyek Kemitraan Super Gaharu. 2010. Manfaat super gaharu. Http:// supergaharu.wordpress.com/gaharu-sekilas/kegunaan-gaharu/. Accessed 14 February 2011.

Pusat Standardisasi dan Lingkungan Departemen Kehutanan. 2002. Gaharu: HHBK yang menjadi primadona. Http://www.dephut.go.id/ Halaman/ Standardisasi_\&_Lingkungan_Kehutanan/Info_V02/VI_V02.htm. Accessed 20 
January 2009.

Rizlani, C. and Aswandi. 2009. Prospek budidaya gaharu secara ringkas. http://laksmananursery.blogspot.com/2009/01/prospek-budidaya-gaharusecara-ringkas.html. Accessed 18 February 2009.

Sidiyasa., K., S. Sutomo and R.S.A. Prawira. 1986. Eksplorasi dan studi permudaan jenis-jenis penghasil gaharu di wilayah Hutan Kintap, Kalimantan Selatan. Buletin Penelitian Hutan 474: 59-66.

Sudarmalik., Y. Rochmayanto and Purnomo. 2006. Peranan beberapa hasil hutan bukan kayu (HHBK) di Riau dan Sumatera Barat. Prosiding Seminar hasil Litbang Hasil Hutan 2006: 199-219. Pusat Litbang Hasil Hutan. Bogor.

Suharti, S. 2009. Prospek pengusahaan gaharu melalui pola pengelolaan hutan berbasis masyarakat (PHBM). Prosiding Workshop: Pengembangan Teknologi Produksi Gaharu Berbasis Pemberdayaan Masyarakat Sekitar Hutan. Pusat Penelitian dan Pengembangan Hutan dan Konservasi Alam, Bogor Bekerjasama dengan ITTO PD 425/06 Rev.I(1). 219 pp.

Sumarna, Y. 2007. Budidaya dan rekayasa produksi gaharu. Temu Pakar Pengembangan Gaharu. Direktorat Jenderal RLPS, Jakarta 15p.

Sumarna, Y. 2008. Beberapa aspek ekologi, populasi pohon dan permudaan alam tumbuhan penghasil gaharu kelompok karas (Aquilaria spp.) di Wilayah Provinsi Jambi. Jurnal Penelitian Hutan dan Konservasi Alam. V (1): 93-99.

Tarmiji, M. 2009. Perhitungan kelayakan usaha gaharu. Http:// wahanagaharu.blogspot. com/2009/08/perhitungan-kelayakan-usahagaharu.html. Accessed 14 November 2009.

The Angel, 2009. Siapkan masa depan, ayo tanam gaharu http:// theangel.wordpress.com/2009/07/25/siapkan-masa-depan-ayo-tanam-gaharu/. Accessed 28 March 2009.

The Wildlife Trade Monitoring Network [TRAFFIC]. 2009. Production and marketing of cultivated agarwood. Factual information about cultivated agarwood. http://www.traffic.org/news/press-releases/wood.htm Accessed 9 February 2009.

Wiguna, I. 2006. Tinggi permintaan terganjal pasokan. Trubus online. http://www.trubusonline.co.id/mod.php? $\bmod =$ publisher\&op = viewarticle\&ci $\mathrm{d}=8 \& \operatorname{artid}=290$ Accessed 16 February 2009. 